\title{
Penyelesaian Persamaan Diferensial Linier Orde Satu dan Dua disertai Nilai Awal dengan menggunakan Metode Runge Kutta Orde Lima Butcher dan Felhberg (RKF45)
}

\author{
Sagita Charolina Sihombing ${ }^{1}$, Agus Dahlia $^{2}$ \\ ${ }^{1}$ Jurusan Fisika Fakultas MIPA, Universitas PGRI Palembang, \\ ${ }^{2}$ Jurusan Pendidikan Matematika, FKIP, Universitas Islam Riau \\ ${ }^{1}$ sagita.charolina@yahoo.com, ${ }^{2}$ agus.dahlia@edu.uir.ac.id
}

\begin{abstract}
Abstrak
Pada makalah ini dibahas penyelesaian persoalan persamaan diferensial linier orde satu dan dua dengan metode hampiran. Metode hampiran yang digunakan adalah metode runge kutta orde lima butcher dan metode runge kutta orde lima Fehlberg (RKF45). Solusi hampiran yang diperoleh dibandingkan dengan solusi analitik untuk mengetahui nilai error dari masing-masing metode. Diperoleh hasil bahwa kedua metode hampiran memberikan nilai penyelesaian yang sama dengan error yang relatif kecil terhadap solusi analitik.

Kata kunci: Metode Runge Kuttta Butcher, Metode Runge Kutta Fehlberg, Solusi Analitik, Persamaan Diferensial Linier Orde 1, Persamaan Diferensial Linier Orde 2 .
\end{abstract}

\begin{abstract}
This paper discussed how to solve the problem of linear differential equations of the first order and the second order with approximation method. The most preferred methods used are the fifth-order runge kutta method of butcher and Fehlberg (RKF45). The approximation solutions obtained are compared with analytical solutions to find out the error values of each method. We found that the two approximation method give the same solution and make small error compare to analytical solution.

Keywords :Runge Kuttta Butcher Method, Runge Kutta Fehlberg Method, Analytical Solution, Linear Differential Equation Order 1, Linear Differential Equation Order 2.
\end{abstract}

\section{Pendahuluan}

Persamaan diferensial menjadi topik yang terus menarik para peneliti untuk mempelajari lebih dalam. Persamaan diferensial sering digunakan untuk pemodelan matematika dalam bidang sains dan teknik (Mathews dan Fink, 1999). Persamaan diferensial merupakan gabungan dari fungsi yang tidak diketahui dengan turunannya. Persamaan diferensial dibedakan menjadi beberapa kategori, kategori pertama adalah persamaan diferensial biasa. Persamaan Diferensial Biasa (PDB) merupakan persamaan diferensial yang hanya memiliki satu variabel

2000 Mathematics Subject Classification: 34A30

Received: 2018-04-23, accepted: 2018-05-08. 
bebas. Turunan dilambangkan dengan $d y / d x$ atau $f^{\prime}(x)$ atau $y^{\prime}$, sedangkan fungsi yang tidak diketahui dilambangkan dengan keberadaan variabel terikatnya, sebagai contoh

$$
\frac{d y}{d x}=x+y
$$

Dari persamaan (1) di atas, maka $\mathrm{x}$ adalah variabel bebas dan y sebagai variabel terikat.

Berdasarkan turunan tertinggi yang dimiliki, PDB dikategorikan menjadi PDB Orde 1 yaitu turunan tertingginya adalah turunan pertama, PDB Orde 2 dengan turunan tertingginya merupakan turunan kedua, begitu juga dengan PDB Orde 3 yakni turunan tertingginya merupakan turunan ketiga, dan seterusnya. Kategori persamaan diferensial lainnya adalah Persamaan Diferensial Parsial (PDP), yakni persamaan diferensial yang memiliki lebih dari satu variabel bebas.

Penyelesaian persamaan diferensial menyangkut pada permasalahan nilai awal dan permasalahan syarat batas. Permasalahan ini dapat diselesaikan secara analitik maupun numerik. Penyelesaian secara analitik memberikan nilai eksak, sedangkan secara numerik memberikan nilai taksiran. Akan tetapi, beberapa persamaan diferensial tidak bisa diselesaikan secara analitik. Oleh sebab itu, para peneliti memperkenalkan beberapa metode numerik untuk menyelesaikan persoalan persamaan diferensial. Untuk permasalahan syarat batas, Dewi E, dkk, 2017, dalam papernya telah membahas penyelesaian persamaan diferensial biasa orde dua menggunakan algoritma shooting neural networks. Untuk Masalah Nilai Awal (MNA), Arisa, dkk, 2014 telah menulis artikel tentang penyelesaian persamaan diferensial untuk persoalan persamaan diferensial Bernoulli menggunakan metode runge kutta orde lima Butcher dan Felhberg (RKF45).

Dari uraian di atas, penulis tertarik untuk membahas tentang persoalan persamaan diferensial menggunakan metode runge kutta orde lima Butcher dan Felhberg (RKF45) untuk persamaan diferensial linier orde satu dan orde dua.Dari hasil yang diperoleh, juga akan dibandingkan metode mana yang paling mendekati solusi analitik.

\section{Metode Penelitian}

Penelitian ini diawali dengan membuat script metode runge kutta orde lima Butcher dan Felhberg (RKF45) pada MATLAB. Setelah itu, diterapkan pada persamaan diferensial linier orde satu dan orde dua. Selanjutnya akan dihitung nilai error dari masing-masing metode untuk mengetahui metode mana yang menghasilkan nilai paling mendekati solusi analitik.

\section{Hasil Dan Pembahasan}

Pada bagian ini akan dibahas penyelesaian PD Linier Orde satu dan PD Linier Orde dua dengan metode hampiran runge kutta orde lima Butcher dan Fehlberg (RKF45). Selanjutnya dicari pula nilai error dari masing-masing metode tersebut untuk mengetahui metode hampiran mana yang memberikan hasil yang paling mendekati nilai analitik.

3.1. Menyelesaikan PD Orde Satu. Suatu fungsi $y=y(x)$ dikatakan solusi persamaan diferensial orde satu $F\left(x, y, y^{\prime}\right)=0$ apabila $y=y(x)$ dan turunannya $y^{\prime}$ memenuhi persamaan tersebut. Sebagai contoh, kita dapat memeriksa bahwa $y=x^{2}+1$ adalah solusi persamaan diferensial: $y^{\prime}=2 x$. Demikian pula $y=x^{2}+C$ untuk $C$ konstanta sebarang juga merupakan solusi persamaan diferensial: $y^{\prime}=2 x$. Solusi $y=x^{2}+1$ disebut sebagai solusi khusus sedangkan solusi $y=x^{2}+C$ disebut sebagai solusi umum. Solusi umum suatu PD masih memuat konstanta $C$, sedangkan solusi khusus diperoleh dari solusi umum dengan mengambil konstanta $\mathrm{C}$ sebagai suatu bilangan tertentu yang memenuhi syarat-syarat yang diberikan, misalnya syarat nilai awal. Bentuk umum persamaan diferensial linier orde satu ditunjukkan pada persamaan berikut ini:

$$
\frac{d y}{d x}=P(x) y=Q(x)
$$


Metode Runge-Kutta adalah alternatif lain dari metode-metode numerik lainnya yang tidak membutuhkan perhitungan turunan. Metode ini berusaha mendapatkan derajat ketelitian yang lebih tinggi, dan sekaligus menghindarkan keperluan mencari turunan yang lebih tinggi.

Metode runge kutta memiliki beberapa orde, salah satunya adalah metode runge kutta orde lima. Metode Runge Kutta orde lima merupakan metode runge kutta yang memiliki enam evaluasi fungsi dan dapat mencapai ketelitian yang akurat dengan menghasilkan nilai hampiran yang mendekati nilai penyelesaian analitik.

Rumus umum metode Runge Kutta orde lima sebagai berikut [1]:

$$
y_{i+1}=y_{i}+\Sigma_{j=1}^{6} b_{j} k_{j}
$$

dengan $j=1,2, \ldots, 6 ; b_{j}$ adalah konstanta dan $k_{j}$ merupakan evaluasi fungsi yang diperoleh dari:

$$
k_{j}=\Delta x \cdot f\left(x_{i}+c_{m} \Delta x, y_{i}+a_{m_{1}} k_{1}+a_{m_{2}} k_{2}+\cdots+a_{m_{m}} k_{m}\right)
$$

$\Delta x$ adalah suatu ukuran langkah yang dinyatakan dengan $\Delta x=x_{i+1}-x_{i}$, sedangkan $c_{m}$ dan $a_{m_{r}}$ adalah konstanta dengan $c_{m}=\Sigma_{r=0}^{m} a_{m_{r}} ; m=j-1, c_{0}=0$ dan $a_{m_{0}}=0$. Metode runge kutta orde lima ini terdiri dari metode Runge Kutta Butcher dan metode Runge Kutta Fehlberg (RKF45).

Adapun langkah-langkah penyelesaian persamaan diferensial orde satu dengan metode runge kutta adalah sebagai berikut:

(1) Membentuk fungsi $f\left(x_{i}, y_{i}\right)$ dengan $i=0,1,2, \ldots, h$

(2) Mencari nilai $k_{j}$ dengan $j=1,2, \ldots, 6$ pada metode runge kutta Butcherdan runge kutta Fehlberg (RKF45) untuk setiap i dan nilai langkah $\Delta x$

(a) Nilai $k_{j}$ pada metode runge kutta Butcher adalah sebaga berikut:

$$
\begin{aligned}
k_{1} & =\Delta x . f\left(x_{i}, y_{i}\right) \\
k_{2} & =\Delta x . f\left(x_{i}+\frac{1}{4} \Delta x, y_{i}+\frac{1}{4} k_{1}\right) \\
k_{3} & =\Delta x . f\left(x_{i}+\frac{1}{4} \Delta x, y_{i}+\frac{1}{8} k_{1}+\frac{1}{8} k_{2}\right) \\
k_{4} & =\Delta x . f\left(x_{i}+\frac{1}{2} \Delta x, y_{i}-\frac{1}{2} k_{2}+k_{3}\right) \\
k_{5} & =\Delta x . f\left(x_{i}+\frac{3}{4} \Delta x, y_{i}+\frac{3}{16} k_{1}+\frac{9}{16} k_{4}\right) \\
k_{6} & =\Delta x . f\left(x_{i}+\Delta x, y_{i}-\frac{3}{7} k_{1}+\frac{2}{7} k_{2}+\frac{12}{7} k_{3}-\frac{12}{7} k_{4}+\frac{8}{7} k_{5}\right)
\end{aligned}
$$

(b) Nilai $k_{j}$ pada metode runge kutta Fehlberg (RKF45) adalah sebaga berikut:

$k_{1}=\Delta x \cdot f\left(x_{i}, y_{i}\right)$

$k_{2}=\Delta x . f\left(x_{i}+\frac{1}{4} \Delta x, y_{i}+\frac{1}{4} k_{1}\right)$

$k_{3}=\Delta x . f\left(x_{i}+\frac{3}{8} \Delta x, y_{i}+\frac{3}{32} k_{1}+\frac{9}{32} k_{2}\right)$

$k_{4}=\Delta x . f\left(x_{i}+\frac{12}{13} \Delta x, y_{i}+\frac{1932}{2197} k_{1}-\frac{7200}{2197} k_{2}+\frac{7296}{2197} k_{3}\right)$

$k_{5}=\Delta x . f\left(x_{i}+\Delta x, y_{i}+\frac{439}{216} k_{1}-8 k_{2}+\frac{3680}{513} k_{3}-\frac{845}{4104} k_{4}\right)$

$k_{6}=\Delta x . f\left(x_{i}+\frac{1}{2} \Delta x, y_{i}-\frac{8}{27} k_{1}+2 k_{2}-\frac{3544}{2565} k_{3}+\frac{1859}{4104} k_{4}-\frac{11}{40} k_{5}\right)$

(3) Mencari nilai taksiran $y_{i+1}$

(a) pada metode runge kutta butcher $y_{i+1}=y_{i}+\frac{1}{90}\left(7 k_{1}+32 k_{3}+12 k_{4}+32 k_{5}+7 k_{6}\right)$

(b) pada metode runge kutta Fehlberg

$$
y_{i+1}=y_{i}+\frac{1}{90}\left(7 k_{1}+32 k_{3}+12 k_{4}+32 k_{5}+7 k_{6}\right)
$$

\section{Percobaan Numerik:}

Misalkan diberikan PD linier orde satu sebagai berikut

$$
\frac{d y}{d x}=x+y ; y(0)=1
$$

Dari persamaan diatas, diketahui $P(x)=-1$ dan $Q(x)=x$.

Dari contoh pada persamaan (5) di atas telah dilakukan perhitungan analitik dan diperoleh 
hasil sebagai berikut:

$$
y=\frac{\frac{1}{2} x^{2}+1}{1-x}
$$

Diperoleh hasil untuk $y(0.10)=1.1103$

Selanjutnya dicari nilai $y(0.10)$ dengan metode Runge Kutta Orde Lima Butcher dan Fehlberg dengan pemisalan ukuran langkah $\Delta x=0.005$.

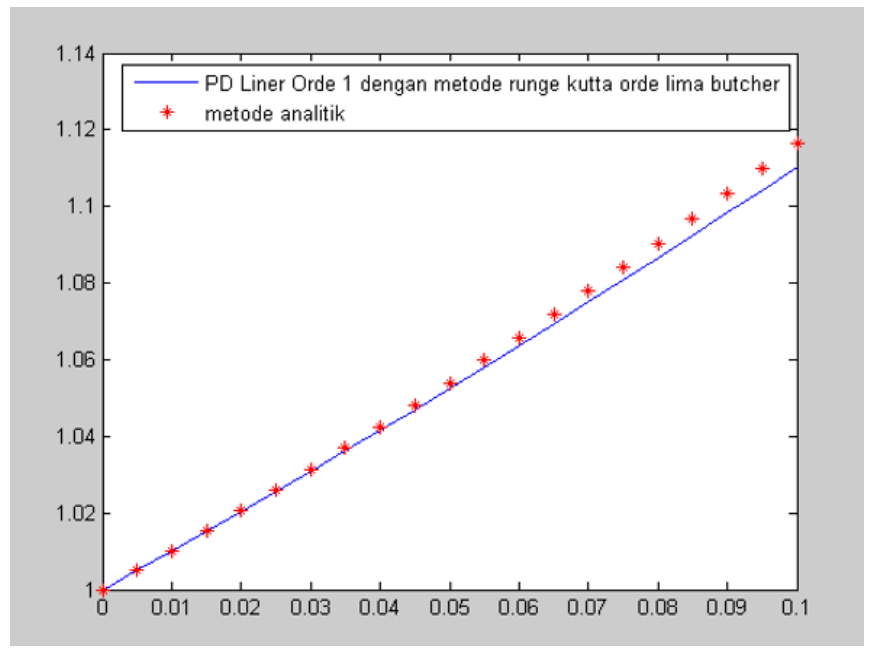

Gambar 1. Perbandingan solusi analitik terhadap solusi hampiran butcher untuk PD Linier Orde 1

TABEL 1. Perbandingan nilai eksak terhadap nilai taksiran butcher untuk PD Linier Orde 2

\begin{tabular}{|c|c|c|c|c|}
\hline$i$ & $x_{i}$ & Solusi Hampiran Butcher $\left(y_{i}\right)$ & Solusi Analitik $\left.\left(y_{x_{i}}\right)\right)$ & Error $\left(y_{i}\right)-\left(y_{x_{i}}\right)$ \\
\hline 0 & 0 & 1.0000 & 1.0000 & 0.0000 \\
\hline 1 & 0.0050 & 1.0050 & 1.0050 & 0.0000 \\
\hline 2 & 0.0100 & 1.0101 & 1.0102 & 0.0001 \\
\hline 3 & 0.0150 & 1.0152 & 1.0153 & 0.0001 \\
\hline 4 & 0.0200 & 1.0204 & 1.0206 & 0.0002 \\
\hline 5 & 0.0250 & 1.0256 & 1.0260 & 0.0003 \\
\hline 6 & 0.0300 & 1.0309 & 1.0314 & 0.0005 \\
\hline 7 & 0.0350 & 1.0362 & 1.0369 & 0.0007 \\
\hline 8 & 0.0400 & 1.0416 & 1.0425 & 0.0009 \\
\hline 9 & 0.0450 & 1.0471 & 1.0482 & 0.0011 \\
\hline 10 & 0.0500 & 1.0525 & 1.0539 & 0.0014 \\
\hline 11 & 0.0550 & 1.0581 & 1.0598 & 0.0017 \\
\hline 12 & 0.0600 & 1.0637 & 1.0657 & 0.0021 \\
\hline 13 & 0.0650 & 1.0693 & 1.0718 & 0.0025 \\
\hline 14 & 0.0700 & 1.0750 & 1.0779 & 0.0029 \\
\hline 15 & 0.0750 & 1.0808 & 1.0841 & 0.0034 \\
\hline 16 & 0.0800 & 1.0866 & 1.0904 & 0.0039 \\
\hline 17 & 0.0850 & 1.0924 & 1.0968 & 0.0044 \\
\hline 18 & 0.0900 & 1.0983 & 1.1034 & 0.0050 \\
\hline 19 & 0.0950 & 1.1043 & 1.1100 & 0.0056 \\
\hline 20 & 0.1000 & 1.1103 & 1.1167 & 0.0063 \\
\hline & & & & \\
\hline
\end{tabular}


Berikut ini perbandingan nilai eksak dengan nilai taksiran Fehlberg (RK45)

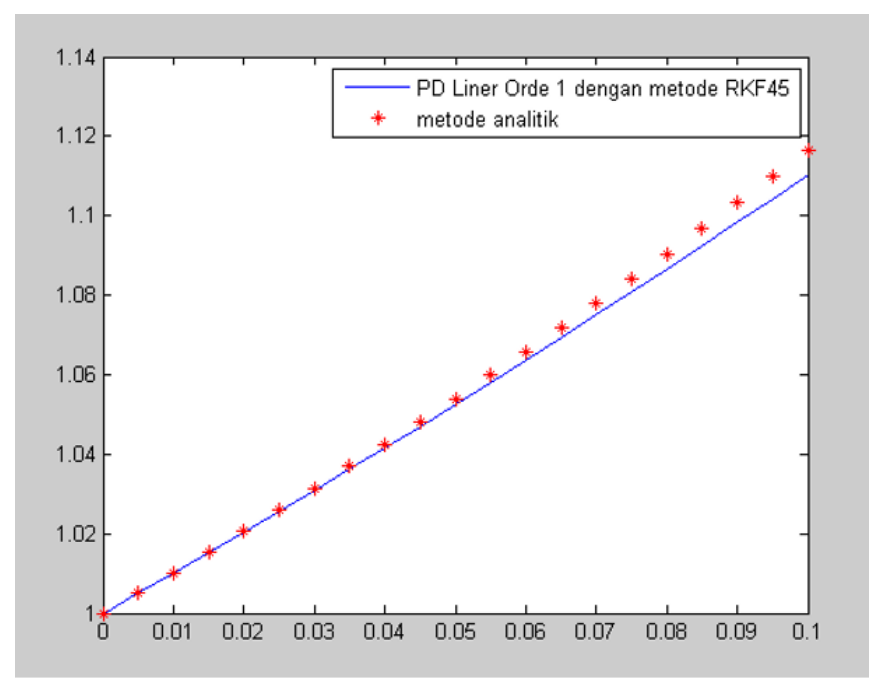

Gambar 2. Perbandingan solusi analitik PD Linier Orde 1 terhadap solusi hampiran metode runge kutta fehlberg orde lima (RKF45)

Adapun untuk taksiran dan errornya diberikan pada tabel berikut ini.

TABEL 2. Perbandingan nilai eksak terhadap nilai taksiran butcher untuk PD Linier Orde 2

\begin{tabular}{|c|c|c|c|c|}
\hline$i$ & $x_{i}$ & Solusi Hampiran RKF45 $\left(y_{i}\right)$ & Solusi Analitik $\left.\left(y_{(} x_{i}\right)\right)$ & Error $\left(y_{i}\right)-\left(y_{x_{i}}\right)$ \\
\hline 0 & 0 & 1.0000 & 1.0000 & 0.0000 \\
\hline 1 & 0.0050 & 1.0050 & 1.0050 & 0.0000 \\
\hline 2 & 0.0100 & 1.0101 & 1.0102 & 0.0001 \\
\hline 3 & 0.0150 & 1.0152 & 1.0153 & 0.0001 \\
\hline 4 & 0.0200 & 1.0204 & 1.0206 & 0.0002 \\
\hline 5 & 0.0250 & 1.0256 & 1.0260 & 0.0003 \\
\hline 6 & 0.0300 & 1.0309 & 1.0314 & 0.0005 \\
\hline 7 & 0.0350 & 1.0362 & 1.0369 & 0.0007 \\
\hline 8 & 0.0400 & 1.0416 & 1.0425 & 0.0009 \\
\hline 9 & 0.0450 & 1.0471 & 1.0482 & 0.0011 \\
\hline 10 & 0.0500 & 1.0525 & 1.0539 & 0.0014 \\
\hline 11 & 0.0550 & 1.0581 & 1.0598 & 0.0017 \\
\hline 12 & 0.0600 & 1.0637 & 1.0657 & 0.0021 \\
\hline 13 & 0.0650 & 1.0693 & 1.0718 & 0.0025 \\
\hline 14 & 0.0700 & 1.0750 & 1.0779 & 0.0029 \\
\hline 15 & 0.0750 & 1.0808 & 1.0841 & 0.0034 \\
\hline 16 & 0.0800 & 1.0866 & 1.0904 & 0.0039 \\
\hline 17 & 0.0850 & 1.0924 & 1.0968 & 0.0044 \\
\hline 18 & 0.0900 & 1.0983 & 1.1034 & 0.0050 \\
\hline 19 & 0.0950 & 1.1043 & 1.1100 & 0.0056 \\
\hline 20 & 0.1000 & 1.1103 & 1.1167 & 0.0063 \\
\hline
\end{tabular}


3.2. Menyelesaikan PD Orde Dua. Persamaan diferensial linier orde dua memiliki bentuk umum sebagai berikut:

$$
p(x) y^{\prime \prime}+q(x) y^{\prime}+r(x) y=s(x)
$$

dengan $p(x), q(x), r(x)$ dan $s(x)$ kontinu pada suatu interval buka $I=(a, b)$. jika $s(x)=0$,

$$
p(x) y^{\prime \prime}+q(x) y^{\prime}+r(x) y=0
$$

Maka persamaan diferensial dikatakan homogen, sebaliknya jika $s(x) \neq 0$, disebut sebagai persamaan diferensial non homogen. Persamaan diferensial orde dua dengan koefisien konstan adalah persamaan (7) dengan $p(x), q(x), r(x)$ adalah fungsi konstan.

Adapun solusi analitik untuk persamaan diferensial orde dua dengan koefisien konstan diberikan pada teorema berikut:

Teorema 3.1. Diberikan persamaan diferensial linier homogen orde 2 dengan koefisien konstan.

$$
y^{\prime \prime}+a y^{\prime}+b y=0, a \neq 0
$$

(1) Jika persamaan karakteristik mempunyai dua akar berbeda $r_{1}$ dan $r_{2}$, maka solusi umum (8) adalah

$$
y(x)=c_{1} e^{r_{1} x}+c_{2} e^{r_{2} x}
$$

(2) Jika persamaan karakteristik mempunyai hanya satu akar $r\left(=\frac{-a}{2}\right.$, maka solusi umum (8) adalah

$$
y(x)=c_{1} e^{r x}+c_{2} e^{r x}
$$

(3) Jika persamaan karakteristik mempunyai dua akar kompleks $r_{1}=\alpha+i \beta$ dan $r_{2}=\alpha-i \beta$, dengan $\alpha=-\frac{a}{2}, \beta=\frac{\sqrt{4 b-a^{2}}}{2}$, maka solusi umum (8) adalah

$$
y(x)=e^{\alpha x}\left(c_{1} \cos \beta+c_{2} \sin \beta\right)
$$

Penyelesaian persamaan diferensial linier orde satu dikembangkan untuk persamaan diferensial linier orde dua. Persamaan diferensial linier orde dua dibentuk menjadi dua persamaan diferensial linier orde satu.

Adapun langkah-langkah penyelesaian persamaan diferensial linier orde dua dengan metode runge kutta adalah sebagai berikut:

(1) Mengkonversi persamaan diferensial linier orde dua menjadi dua bentuk persamaan diferensial orde satu $f\left(x_{i}, y_{i}, z_{i}\right)$ dan $g\left(x_{i}, y_{i}, z_{i}\right)$ dengan $i=0,1,2, \ldots, h$

(2) Mencari nilai $k_{j}$ dengan $j=1,2, \ldots, 6$ pada metode runge kutta Butcher dan runge kutta Fehlberg untuk setiap $i$ dan nilai langkah $\Delta x$

(a) Nilai $k_{j}$ pada metode runge kutta Butcher adalah sebaga berikut:

$$
\begin{aligned}
k_{1}= & \Delta x . f\left(x_{i}, y_{i}, z_{i}\right) \\
k_{2}= & \Delta x . f\left(x_{i}+\frac{1}{4} \Delta x, y_{i}+\frac{1}{4} k_{1}, z_{i}+\frac{1}{4} l_{1}\right) \\
k_{3}= & \Delta x \cdot f\left(x_{i}+\frac{1}{4} \Delta x, y_{i}+\frac{1}{8} k_{1}+\frac{1}{8} k_{2}, z_{i}+\frac{1}{8} l_{1}+\frac{1}{8} l_{2}\right) \\
k_{4}= & \Delta x . f\left(x_{i}+\frac{1}{2} \Delta x, y_{i}-\frac{1}{2} k_{2}+k_{3} z_{i}-\frac{1}{2} l_{2}+l_{3}\right) \\
k_{5}= & \Delta x . f\left(x_{i}+\frac{3}{4} \Delta x, y_{i}+\frac{3}{16} k_{1}+\frac{9}{16} k_{4}, z_{i}+\frac{3}{16} l_{1}+\frac{9}{16} l_{4}\right) \\
k_{6}= & \Delta x \cdot f\left(x_{i}+\Delta x, y_{i}-\frac{3}{7} k_{1}+\frac{2}{7} k_{2}+\frac{12}{7} k_{3}-\frac{12}{7} k_{4}+\frac{8}{7} k_{5}, z_{i}-\frac{3}{7} l_{1}+\frac{2}{7} l_{2}+\right. \\
& \left.\frac{12}{7} l_{3}-\frac{12}{7} l_{4}+\frac{8}{7} l_{5}\right) \\
\text { dan } &
\end{aligned}
$$




$$
\begin{aligned}
l_{1}= & \Delta x . g\left(x_{i}, y_{i}, z_{i}\right) \\
l_{2}= & \Delta x . g\left(x_{i}+\frac{1}{4} \Delta x, y_{i}+\frac{1}{4} k_{1}, z_{i}+\frac{1}{4} l_{1}\right) \\
l_{3}= & \Delta x . g\left(x_{i}+\frac{1}{4} \Delta x, y_{i}+\frac{1}{8} k_{1}+\frac{1}{8} k_{2}, z_{i}+\frac{1}{8} l_{1}+\frac{1}{8} l_{2}\right) \\
l_{4}= & \Delta x . g\left(x_{i}+\frac{1}{2} \Delta x, y_{i}-\frac{1}{2} k_{2}+k_{3} z_{i}-\frac{1}{2} l_{2}+l_{3}\right) \\
l_{5}= & \Delta x . g\left(x_{i}+\frac{3}{4} \Delta x, y_{i}+\frac{3}{16} k_{1}+\frac{9}{16} k_{4}, z_{i}+\frac{3}{16} l_{1}+\frac{9}{16} l_{4}\right) \\
l_{6}= & \Delta x . g\left(x_{i}+\Delta x, y_{i}-\frac{3}{7} k_{1}+\frac{2}{7} k_{2}+\frac{12}{7} k_{3}-\frac{12}{7} k_{4}+\frac{8}{7} k_{5}, z_{i}-\frac{3}{7} l_{1}+\frac{2}{7} l_{2}+\right. \\
& \left.\frac{12}{7} l_{3}-\frac{12}{7} l_{4}+\frac{8}{7} l_{5}\right)
\end{aligned}
$$

(b) Nilai $k_{j}$ pada metode runge kutta Fehlberg (RKF45) adalah sebaga berikut:

$$
\begin{aligned}
& k_{1}=\Delta x . f\left(x_{i}, y_{i}, z_{i}\right) \\
& k_{2}=\Delta x \cdot f\left(x_{i}+\frac{1}{4} \Delta x, y_{i}+\frac{1}{4} k_{1}, z_{i}+\frac{1}{4} l_{1}\right) \\
& k_{3}=\Delta x . f\left(x_{i}+\frac{3}{8} \Delta x, y_{i}+\frac{3}{32} k_{1}+\frac{9}{32} k_{2}, z_{i}+\frac{3}{32} l_{1}+\frac{9}{32} l_{2}\right) \\
& k_{4}=\Delta x . f\left(x_{i}+\frac{12}{13} \Delta x, y_{i}-\frac{1932}{2197} k_{1}-\frac{7200}{2197} k_{2}+\frac{7296}{2197} k_{3} z_{i}+\frac{1932}{2197} l_{1}-\frac{7200}{2197} l_{2}+\frac{7296}{2197} l_{3}\right) \\
& k_{5}=\Delta x . f\left(x_{i}+\Delta x, y_{i}-\frac{439}{216} k_{1}-8 k_{2}+\frac{3680}{513} k_{3}-\frac{845}{4104} k_{4}, z_{i}+\frac{439}{216} l_{1}-8 l_{2}+\frac{3680}{513} l_{3}+\frac{9}{16} l_{4}\right) \\
& k_{6}=\Delta x . f\left(x_{i}+\frac{1}{2} \Delta x, y_{i}-\frac{8}{27} k_{1}+2 k_{2}-\frac{3544}{2565} k_{3}+\frac{1859}{4104} k_{4}-\frac{11}{40} k_{5}, z_{i}-\frac{8}{27} l_{1}+2 l_{2}-\right. \\
& \left.\frac{3544}{2565} l_{3}+\frac{1859}{4104} l_{4}-\frac{11}{40} l_{5}\right) \\
& \operatorname{dan}_{l_{1}}=\Delta x . g\left(x_{i}, y_{i}, z_{i}\right) \\
& l_{2}=\Delta x . g\left(x_{i}+\frac{1}{4} \Delta x, y_{i}+\frac{1}{4} k_{1}, z_{i}+\frac{1}{4} l_{1}\right) \\
& l_{3}=\Delta x . g\left(x_{i}+\frac{3}{8} \Delta x, y_{i}+\frac{3}{32} k_{1}+\frac{9}{32} k_{2}, z_{i}+\frac{3}{32} l_{1}+\frac{9}{32} l_{2}\right) \\
& l_{4}=\Delta x . g\left(x_{i}+\frac{12}{13} \Delta x, y_{i}-\frac{1932}{2197} k_{1}-\frac{7200}{2197} k_{2}+\frac{7296}{2197} k_{3} z_{i}+\frac{1932}{2197} l_{1}-\frac{7200}{2197} l_{2}+\frac{7296}{2197} l_{3}\right) \\
& l_{5}=\Delta x . g\left(x_{i}+\Delta x, y_{i}-\frac{439}{216} k_{1}-8 k_{2}+\frac{3680}{513} k_{3}-\frac{845}{4104} k_{4}, z_{i}+\frac{439}{216} l_{1}-8 l_{2}+\frac{3680}{513} l_{3}+\frac{9}{16} l_{4}\right) \\
& l_{6}=\Delta x . g\left(x_{i}+\frac{1}{2} \Delta x, y_{i}-\frac{8}{27} k_{1}+2 k_{2}-\frac{3544}{2565} k_{3}+\frac{1859}{4104} k_{4}-\frac{11}{40} k_{5}, z_{i}-\frac{8}{27} l_{1}+2 l_{2}-\right. \\
& \left.\frac{3544}{2565} l_{3}+\frac{1859}{4104} l_{4}-\frac{11}{40} l_{5}\right)
\end{aligned}
$$

(3) Mencari nilai taksiran $y_{i+1}$

(a) pada metode runge kutta butcher

$$
\begin{aligned}
& y_{i+1}=y_{i}+\frac{1}{90}\left(7 k_{1}+32 k_{3}+12 k_{4}+32 k_{5}+7 k_{6}\right) \\
& z_{i+1}=z_{i}+\frac{1}{90}\left(7 l_{1}+32 l_{3}+12 l_{4}+32 l_{5}+7 l_{6}\right)
\end{aligned}
$$

(b) pada metode runge kutta Fehlberg

$$
\begin{aligned}
& y_{i+1}=y_{i}+\frac{25}{216} k_{1}+\frac{1408}{2564} k_{3}+\frac{2197}{4110} k_{4}-\frac{1}{5} k_{5} \\
& z_{i+1}=z_{i}+\frac{16}{135} l_{1}+\frac{6656}{12825} l_{3}+\frac{28561}{56430} l_{4}-\frac{9}{50} l_{5}+\frac{2}{55} l_{6}
\end{aligned}
$$

\section{Percobaan Numerik:}

Misalkan diberikan PD linier orde dua,

$$
\frac{d^{2} y}{d x^{2}}=\frac{d y}{d x}-6 y=0
$$

dengan $y(0)=3$ dan $y^{\prime}(0)=1$.

Secara analitik, Persamaan karakteristik dari persoalan (9) di atas adalah:

Diperoleh solusi umum

$$
\begin{gathered}
r^{2}+r-6=0 \\
(r-2)(r+3)=0
\end{gathered}
$$

$$
y(x)=c_{1} e^{2 x}+c_{2} e^{-3 x}
$$

Dengan nilai awal $y(0)=3$ dan $y^{\prime}(0)=1$, maka

$$
\begin{gathered}
c_{1}+c_{2}=3 \\
2 c_{1}-3 c_{2}=1
\end{gathered}
$$

Dengan mensubstitusi $c_{1}=3-c_{2}$ ke (11), maka

$2\left(3-c_{2}\right)-3 c_{2}=1$

$6-5 c_{2}=1$

$c_{2}=1, c_{1}=2$

Solusi khusus: $y(x)=2 e^{2} x+e^{-3 x}$ 
Penyelesaian persoalan (9) dilakukan dengan terlebih dahulu mengkonversi menjadi dua bentuk PDB orde satu berikut ini:

$$
\left\{\begin{array}{l}
\frac{d y}{d x}=z \\
\frac{d z}{d x}=6 y-z
\end{array}\right.
$$

dengan $y(0)=3 \operatorname{dan} z(0)=1$. Sistem yang akan diselesaikan adalah

$$
\begin{gathered}
\frac{d y}{d x}=f(x, y, z)=z \\
\frac{d z}{d x}=g(x, y, z)=6 y-z
\end{gathered}
$$

Selanjutnya dilakukan perhitungan dengan metode runge kutta orde lima Butcher dan Fehlberg dengan bantuan Matlab.

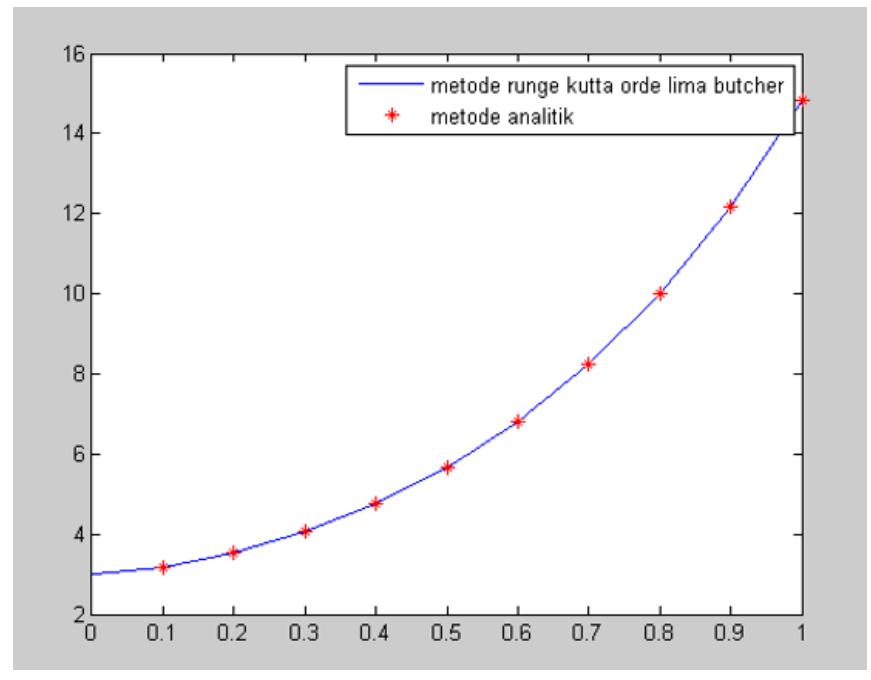

Gambar 3. Perbandingan solusi analitik terhadap solusi hampiran metode runge kutta butcher orde lima

Adapun untuk taksiran dan errornya diberikan pada tabel berikut ini:

TABEL 3. Perbandingan nilai eksak terhadap nilai taksiran butcher untuk PD Linier Orde 2

\begin{tabular}{|c|c|c|c|c|}
\hline $\mathrm{i}$ & $x_{i}$ & Nilai taksiran Butcher $\left(y_{i}\right)$ & Nilai eksak $\left(y_{x_{i}}\right)$ & Error $\left.\left(y_{i}\right)-\left(y_{x_{i}}\right)\right)$ \\
\hline 0 & 0 & 3.0000 & 3.0000 & 0.0000 \\
\hline 1 & 0.1 & 3.1836 & 3.1836 & 0.0000 \\
\hline 2 & 0.2 & 3.5325 & 3.5325 & 0.0000 \\
\hline 3 & 0.3 & 4.0508 & 4.0508 & 0.0000 \\
\hline 4 & 0.4 & 4.7523 & 4.7523 & 0.0000 \\
\hline 5 & 0.5 & 5.6597 & 5.6597 & 0.0000 \\
\hline 6 & 0.6 & 6.8055 & 6.8055 & 0.0000 \\
\hline 7 & 0.7 & 8.2329 & 8.2329 & 0.0000 \\
\hline 8 & 0.8 & 9.9968 & 9.9968 & 0.0000 \\
\hline 9 & 0.9 & 12.1665 & 12.1665 & 0.0000 \\
\hline 10 & 1 & 14.8279 & 14.8279 & 0.0000 \\
\hline
\end{tabular}


Dari tabel di atas, diketahui bahwa nilai taksiran Fehlberg (RKF45) memberikan nilai yang sama dengan nilai eksak.

Berikut ini perbandingan nilai eksak dengan nilai taksiran Fehlberg (RK45)

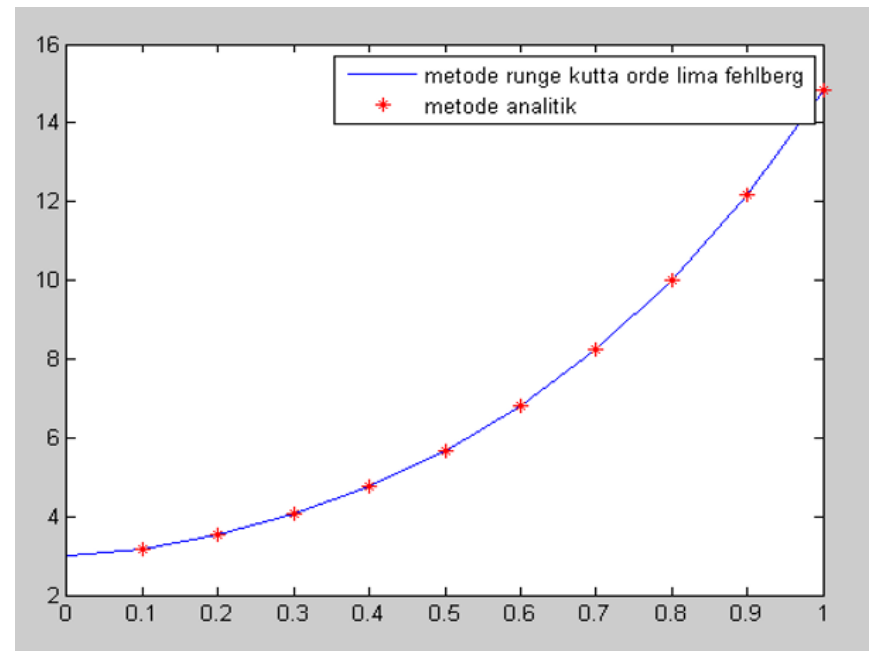

Gambar 4. Perbandingan nilai eksaik terhadap nilai taksiran metode runge kutta Fehlberg orde lima

Adapun untuk taksiran dan errornya diberikan pada tabel berikut ini:

TABEL 4. Perbandingan solusi analitik terhadap solusi hampiran Fehlberg (RKF45) untuk PD Linier Orde 2

\begin{tabular}{|c|c|c|c|c|}
\hline$i$ & $x_{i}$ & Nilai taksiran RKF45 $\left(y_{i}\right)$ & Nilai eksak $\left(y_{x_{i}}\right)$ & Error $\left(y_{i}\right)-\left(y_{x_{i}}\right)$ \\
\hline 0 & 0 & 3.0000 & 3.0000 & 0.0000 \\
\hline 1 & 0.1 & 3.1836 & 3.1836 & 0.0000 \\
\hline 2 & 0.2 & 3.5325 & 3.5325 & 0.0000 \\
\hline 3 & 0.3 & 4.0508 & 4.0508 & 0.0000 \\
\hline 4 & 0.4 & 4.7523 & 4.7523 & 0.0000 \\
\hline 5 & 0.5 & 5.6597 & 5.6597 & 0.0000 \\
\hline 6 & 0.6 & 6.8055 & 6.8055 & 0.0000 \\
\hline 7 & 0.7 & 8.2328 & 8.2329 & -0.0001 \\
\hline 8 & 0.8 & 9.9968 & 9.9968 & 0.0000 \\
\hline 9 & 0.9 & 12.1665 & 12.1665 & 0.0000 \\
\hline 10 & 1 & 14.8279 & 14.8279 & 0.0000 \\
\hline
\end{tabular}

Dari tabel di atas, diketahui bahwa nilai taksiran Fehlberg memberikan nilai yang sama dengan nilai eksak.

\section{Simpulan}

Dari hasil penelitian di atas diperoleh bahwa:

(1) Untuk persamaan diferensial linier orde 1 dan 2 , solusi hampiran metode runge kutta orde lima butcher dan metode orde lima fehlberg (RKF45) memberikan solusi yang sama.

(2) Nilai penyelesaian untuk kedua metode tersebut memberikan error yang relative sangat kecil terhadap solusi analitik. 


\section{DAFTAR Pustaka}

[1] Abraham, O. and Bolarin, G. On error estimation in Runge-Kutta methods, Leonardo Journal of Sciences, Vol 18, page 1-10; 2011

[2] Aga SA dan Ekpenyong FE. Upgrading Runge-Kutta-Fehlberg Method (RKFM) for Second Order Ordinary Differential Equations, International Journal of Science and Technology Vol 3 No. 4, page 258 - $263 ; 2013$

[3] Ahmad N and Charan S. Numerical Accuracy Between Runge Kutta Fehlberg Method and AdamsBashforth Method for First Order Ordinary Differential Equations with Boundary Value Problem. J. Math. Comput. Sci.6, No. 6, page 1145 - 1156; 2016

[4] Arisa R, dkk. Penyelesaian Persaman Diferensial Bernouli Menggunakan Runge Kutta Orde Lima, Buletin Ilmiah Mat. Stat. dan Terapannya (Bimaster) Vol 03, No. 3, hal 193 - 200; 2014

[5] Bu S, Chung W, and Kim P. Method for Improving the Embedded Runge Kutta Fehlberg 4(5). Internaational Journal of Mathematical and Computational Sciences. Vol 8, No. 8, page 1101 - $1103 ; 2014$

[6] Burden dan Faires. Numerical Analysis Cengage Learning. 9th Edition International Edition; 2010

[7] Butcher J. Runge-Kutta Methods for Ordinary Differential Equations. COE Workshop Analysis, Kyushu University, May 2015

[8] Dewi E, dkk. Penyelesaian Masalah Syarat Batas dalam Persamaan Diferensial Biasa Orde Dua dengan Menggunakan Algoritma Shooting Neural Networks. Teknikom. Vol 01, No. 2, hal 67 - 78; 2017

[9] Militaru R. An Adaptive Stepsize Algorithm for The Numerical Solving of Initial-Value Problems. Versita. Vol 23, No. 1, page 185 - 198; 2015 